ISSN 1681-116X. Украӥнський соціум. 2016. № 1(56)

УДК 616.89:578.828ВІЛ](477.64-25)

Leigh M. McClarty, Centre for Global Public Health, Department of Community Health Sciences, University of Manitoba, Winnipeg, Canada,

Marissa L. Becker, Centre for Global Public Health, Department of Community Health Sciences, University of Manitoba, Winnipeg, Canada,

Daryna Pavlova, Ukrainian Institute for Social Research after Olexandr Yaremenko, Kyiv, Ukraine,

Shajy Isac, Centre for Global Public Health, Department of Community Health Sciences, University of Manitoba, Winnipeg, Canada, Karnataka Health Promotion Trust, Bangalore, India,

Faran Emmanuel, Centre for Global Public Health, Department of Community Health Sciences, University of Manitoba, Winnipeg, Canada,

Olga Balakireva, Ukrainian Institute for Social Research after Olexandr Yaremenko, Kyiv, Ukraine,

Tetiana Bondar, Ukrainian Institute for Social Research after Olexandr Yaremenko, Kyiv, Ukraine,

Iana Sazonova, International HIV/AIDS Alliance in Ukraine, Kyiv, Ukraine,

Olena Sakovych, UNICEF Ukraine, Kyiv, Ukraine,

James F. Blanchard, Centre for Global Public Health, Department of Community Health Sciences, University of Manitoba, Winnipeg, Canada

\title{
CHARACTERIZING HIV RISK AND VULNERABILITY AMONG COMMERCIAL SEX WORKERS IN ZAPORIZHZHYA, UKRAINE
}

The paper presents an analysis of numerous individual-level risk factors, as well as social and structural vulnerabilities for HIV faced by commercial sex workers in Zaporizhzhya. Combination HIV prevention programmes that integrate behavioural, biomedical, and structural interventions are recommended to expand upon existing, local prevention efforts in Zaporizhzhya, and Ukraine more broadly.

Keywords: HIV, commercial sex workers, risk groups vulnerable groups, HIV prevention programs.

Introduction. Ukraine is experiencing one of the fastest growing HIV epidemics in Europe [1-3]. The most recent estimates indicate that approximately $0,58 \%$ of the adult population (15-49 years) is living with HIV [4], with certain key populations - including commercial sex workers (CSW), people who inject drugs (PWID), men who have sex with men (MSM), and street involved youth (SIY) being disproportionately burdened by the epidemic [3; 5-9]. Importantly, a systematic review and meta-analysis by Baral and colleagues found that the odds of being infected with HIV is ten-times greater for self-identified CSW in Ukraine than for women who do not report involvement in sex work. Additionally, Ukrainian surveillance data from 2013 indicates that HIV prevalence among CSW who do not inject drugs is at least $5,8 \%$, but this prevalence increases greatly, to $27,6 \%$ among CSW who also inject drugs [9]. 
Although programme coverage for CSW in Ukraine is quite high, a smaller proportion $(64,5 \%)$ of young CSW, <25 years old, are reached by HIV prevention programmes, when compared to older $\mathrm{CSW} \geq 25(72,7 \%)$ [9]. Indeed, previous research in low- and middle-income countries has noted that HIV prevention programme models that have been successful with older and established CSW often have outreach and service gaps for younger CSW and those just entering into sex work [10- 12]. As such, once infected, younger women who are at risk of acquiring HIV, including young CSW, may also be likely to experience delays and gaps in important health services, including HIV treatment, care, and support [13]. Compounding this issue is the lack of health service linkages with the child protection- and childcare systems in Ukraine [14], as well as adversarial interactions with the police (militsiya) and legal systems.

In order to inform HIV prevention and care services in Zaporizhzhya, the University of Manitoba's Centre for Global Public Health (CGPH), the International Centre for Infectious Diseases (ICID), and the Ukrainian Institute for Social Research after Olexandr Yaremenko (UISR), with support from UNICEF Ukraine, carried out an epidemiological mapping and rapid HIV epidemic appraisal project from October 2012 through February 2013. Zaporizhzhya was selected as the study site for this project for multiple reasons. First, although very little is currently known about the HIV epidemic in Zaporizhzhya, the city appears to be particularly vulnerable to increasing rates of infection given its geographic location between the eastern and southern regions of the country, which are disproportionately burdened by HIV $[1 ; 15 ; 16]$. Additionally, HIV prevention programme coverage for the Zaporizhzhya oblast is quite low at 22,9\%, with $572 \mathrm{CSW}$ reached out of the estimated 2,500 CSW operating in the area [17; 18]. Here, we present data from a behavioural assessment component of the rapid epidemic appraisal project, with the hopes of enriching the limited body of literature currently available on CSW in Ukraine. We specifically examine self-reported behaviours that shape HIV vulnerability and place CSW in Zaporizhzhya at increased risk for HIV infection.

Research Procedures and Methodology. The involvement of CSW, through peer groups, as well as other key stakeholders in local HIV prevention programmes was of central importance while conducting the epidemic appraisal in Zaporizhzhya. Although an independent research team collected data, peer group members and local non-governmental organizations (NGOs) with a good rapport among CSW communities were involved at each step of the study.

Sample selection. A multistage, stratified cluster sampling approach was used to identify CSW participants for this study. The first stage of sampling involved the development of a list of all active «hotspots» that had been identified by key informants as places where women involved in sex work congregate, with the purpose of meeting partners or clients. The list of hotspots was then stratified by geographic location, and all CSW hotspots within a particular geographic region of Zaporizhzhya formed a primary sampling unit (PSU). A target sample size of $125 \mathrm{CSW}$ across twenty-five PSUs was pre-established. To select each PSU, probability proportion to size (PPS) methods were employed [19], using the estimated number of CSW at each hotspot as a proxy for overall population size. The PPS selection was done after stratifying hotspots by CSW typology (e.g., brothel/apartment-based, venue-based, home-based), so as to ensure adequate representation and proportionate distribution of sample respondents from each typology. A more detailed description of similar sampling methodologies can be found elsewhere [20;21].

In the second stage of sampling, women who self-identified as CSW, were between the ages of 15 and 24 years, and were actively practicing sex work at the time of recruitment were randomly selected from PSUs. Briefly, the sample size of participants from each PSU was determined based on the estimated number of CSW in the randomly selected hotspots within the PSU, such that the number of 
CSW sampled within a given hotspot was proportional to the estimated CSW population size within the larger PSU.

Data collection. One research coordinator from UISR was responsible for the overall data collection process, working closely with the site supervisors to coordinate and provide guidance for all data collection activities. A team of field researchers conducted structured interviews with CSW participants to gather information about participants' sexual behaviours and drug use practices using a standard quantitative tool. The field team comprised individuals from Zaporizhzhya who had previous experience working with local CSW communities and (or) self-identified as CSW through the charitable foundation, Spodivannya [22]. Among the research team, individuals had roles as: supervisors, who were responsible for the overall management of the field team; interviewers, who assumed the responsibility of ensuring that all study participants fully understood study procedures and administering the structured interviews; and community mobilizers, who contacted identified participants and then screening for eligibility after a period of one-on-one interaction with the participants to build rapport. All interviewers took part in a four-day training session focusing on interviewing techniques and how to protect the confidentiality and rights of participants. Furthermore, all field team members were trained on the fundamentals of research ethics.

Data management and analysis. Data collection tools were edited by field teams on a daily basis and corrected for any missing information. Data entry operators, who were overseen by a database manager, populated databases with built-in quality checks. The team was trained on data quality and consistency, data entry, and data management. The data was entered into an SPSS-based database, under the supervision of the data manager, with support from CGPH.

The CGPH technical team performed descriptive analysis to produce frequencies, proportions, and comparative statistics, with the UISR team providing context, critical input, and validity-checks to inform analyses.

Ethical considerations. This study received ethical approval from the Health Research Ethics Board at the University of Manitoba in Winnipeg, Canada and the Ethical Review Committee of the Sociological Association of Ukraine in Kyiv.

Prior to obtaining verbal consent, all participants were provided with a thorough briefing of the study's purpose and an explanation of the research procedures, including data collection and utilization of data. Protocols that would ensure participants' confidentiality were also reviewed: no identifying information was sought from participants and all questionnaires used a study site code for identification. Informed verbal consent was obtained prior to the commencement of the survey, and a small honorarium was provided to participants to compensate for their time, travel, and participation in the study.

Results. Participant characteristics. A total of 124 CSW were interviewed. Sociodemographic characteristics are presented in Table 1. The mean age of participants was 21,5 years with 18,5\% of participants younger than 20 years of age. Approximately one-quarter of participants had completed high school and a further two-fifths had obtained vocational training; however, almost all CSW indicated that their main source of income was from sex work.

The mean reported age at the start of sex work was 15,7 years. On average, participants practiced sex work 6,2 days per week and 26,7 days per month. Over $40 \%$ of participants indicated that their sex work is street-based, while the most commonly reported methods for meeting clients and arranging dates were via telephone or in public places such as bars, restaurants, night clubs, and the street (Figure 1). Although the majority of women reported living in Zaporizhzhya at the time the survey was conducted, many indicated that they had practiced sex work outside of the city. 
Table 1

Descriptive characteristics of female sex worker participants in Zaporizhzhya $(N=124)$

\begin{tabular}{|c|c|c|}
\hline Sociodemographic characteristics & $n$ & $(\%)$ \\
\hline \multicolumn{3}{|l|}{ Age (years) } \\
\hline$<20$ & 23 & $(18,5)$ \\
\hline$\geq 20$ & 101 & $(81,5)$ \\
\hline Mean age & \multicolumn{2}{|c|}{21,5} \\
\hline \multicolumn{3}{|l|}{ Education level $^{\mathrm{a}}$} \\
\hline Completed middle school & 19 & $(15,6)$ \\
\hline Completed high school & 30 & $(24,6)$ \\
\hline Vocational education & 49 & $(40,1)$ \\
\hline Undergraduate or higher & 24 & $(19,7)$ \\
\hline Currently in school/studying & 15 & $(12,1)$ \\
\hline \multicolumn{3}{|l|}{ Main source of income } \\
\hline Employment (full/part time) & 4 & $(3,2)$ \\
\hline Sex work & 120 & $(96,8)$ \\
\hline \multicolumn{3}{|l|}{ Work other than sex work ${ }^{b}$} \\
\hline Yes & 11 & $(9,2)$ \\
\hline No & 108 & $(90,8)$ \\
\hline \multicolumn{3}{|l|}{ Sex work-related characteristics } \\
\hline \multicolumn{3}{|l|}{ Age at start of sex work (years) } \\
\hline$<15$ & 23 & $(18,5)$ \\
\hline$\geq 15$ & 69 & $(55,6)$ \\
\hline Do not remember & 32 & $(25,8)$ \\
\hline Mean age & \multicolumn{2}{|c|}{15,7} \\
\hline \multicolumn{3}{|l|}{ Reason for entering sex work } \\
\hline To be able to meet personal expenses & 49 & $(39,5)$ \\
\hline No source of income/no money & 34 & $(27,4)$ \\
\hline Other & 41 & $(33,1)$ \\
\hline Mean number of days/week practicing sex work & \multicolumn{2}{|c|}{6,2} \\
\hline Mean number of days/month practicing sex work & \multicolumn{2}{|c|}{26,7} \\
\hline \multicolumn{3}{|l|}{ Typology } \\
\hline Street-based & 51 & $(41,1)$ \\
\hline Brothel/apartment-based & 28 & $(22,7)$ \\
\hline Venue-based (e.g., bar, nightclub, casino) & 21 & $(16,9)$ \\
\hline Massage parlour-based & 18 & $(14,5)$ \\
\hline Home-based & 6 & $(4,8)$ \\
\hline Ever practiced SW in city other than Zaporizhzhya $^{\mathrm{c}}$ & 40 & $(41,2)$ \\
\hline
\end{tabular}

${ }^{\mathrm{a}}$ Valid $n=122 ;{ }^{\mathrm{b}}$ Valid $n=119 ;{ }^{\mathrm{c}}$ Valid $n=97$. 


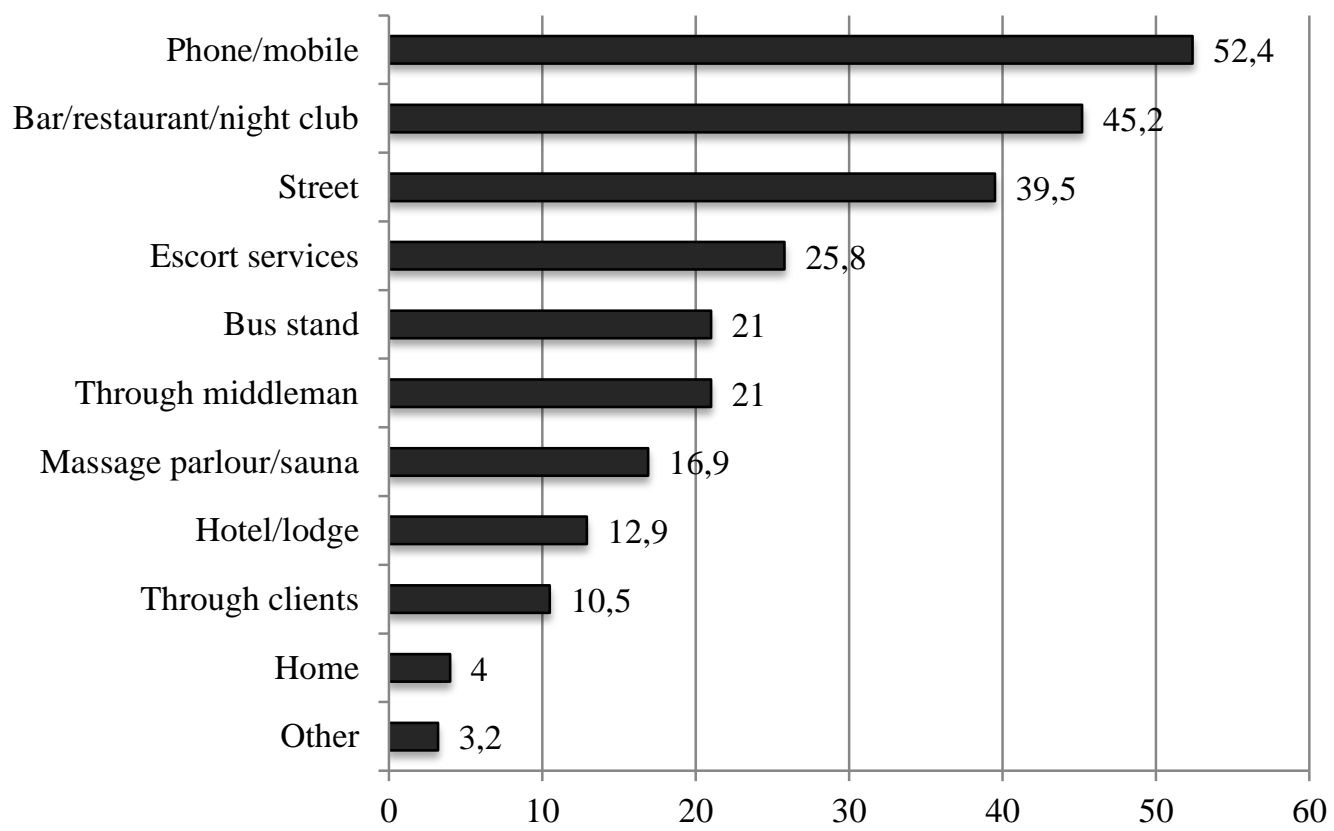

Figure 1. Locations and methods used by female sex workers to meet clients in Zaporizhzhya $(N=124)$, \%

HIV knowledge and HIV testing behaviours. Table 2 presents HIV knowledge and HIV testing history among CSW participants. While nearly all CSW had heard of HIV, only 55\% felt that they were at risk of becoming infected, and less than half had ever been tested for HIV. Of the 75 participants $(60,5 \%)$ who had never been tested for HIV, only $15(20 \%)$ provided some reason for why they had not tested. Most stated that they simply did not want to have the test done; while a few felt that their sexual behaviour was already safe.

Table 2

HIV knowledge and testing among female sex workers in Zaporizhzhya $(N=124)$

\begin{tabular}{|l|c|c|}
\hline \multicolumn{1}{|c|}{ HIV knowledge } & $n$ & $\%$ \\
\hline Ever heard of HIV/AIDS $_{1}$ HIV testing behaviours & 122 & $(98,3)$ \\
\hline Feel at risk for HIV $^{\mathrm{a}}$ & 67 & $(55,4)$ \\
\hline \multicolumn{1}{|c|}{} & & \\
\hline Ever tested $^{\mathrm{b}}$ & 49 & $(40,2)$ \\
\hline Self-initiated testing & & \\
\hline Yes & 30 & $(24,2)$ \\
\hline No & 19 & $(15,3)$ \\
\hline Never tested & 75 & $(60,5)$ \\
\hline Time of last HIV test $^{\mathrm{c}}$ & & \\
\hline$<1$ year ago & 28 & $(63,6)$ \\
\hline 1 year ago & 8 & $(18,2)$ \\
\hline$\geq 2$ years ago & 8 & $(18,2)$ \\
\hline
\end{tabular}


Table 2 continuation

\begin{tabular}{|l|c|c|}
\hline Reasons for not being tested for HIV & & \\
\hline Do not want to be tested & 10 & $(66,6)$ \\
\hline My sexual behaviour is safe & 3 & $(20,0)$ \\
\hline Scared of test results & 1 & $(6,7)$ \\
\hline Test is expensive & 1 & $(6,7)$ \\
\hline
\end{tabular}

${ }^{\mathrm{a}}$ Valid $n=121 ;{ }^{\mathrm{b}}$ Valid $n=122 ;{ }^{\mathrm{c}}$ Valid $n=44 ;{ }^{\mathrm{d}}$ Valid $n=15$.

HIV vulnerabilities and overlapping risk behaviours among female sex workers in Zaporizhzhy.

Sexual behaviours. Participants were asked about the number of sexual partners and clients with whom they had relations and these findings are presented in Table 3. On average, CSW in Zaporizhzhya reported 10,3 sexual partners in the past one-week, and 60,9 clients in the past six months. Boyfriends/lovers were the most common type of sexual partner named by CSW, followed by strangers and "other", which would include clients (Figure 2). Most CSW ( $n=69 ; 55,6 \%)$ reported seeing at least three clients in the last one-day, but $44,3 \%(n=55)$ were unable to recall how many clients they had seen in the last one-week. Importantly, most women indicated that of their last ten clients, the majority were occasional $(n=109 ; 88,6 \%)$, and anal sex with male clients/partners was common $(n=93 ; 75,0 \%)$. Notably, a large proportion of CSW participants reported that they were unable to recall how many sexual partners and/or clients they had seen in the past one week.

Self-reported sexual behaviours and condom use among female sex workers $(N=124)$

\begin{tabular}{|l|c|c|}
\hline \multicolumn{1}{|c|}{ Sexual behaviours } & $\boldsymbol{n}$ & $\mathbf{\%}$ \\
\hline Mean number of sexual partners & \multicolumn{2}{|c|}{2,9} \\
\hline Last day & \multicolumn{2}{|c|}{10,3} \\
\hline Last week & \multicolumn{2}{|c|}{60,9} \\
\hline Last 6 months & & \\
\hline Number of sexual partners in the past 7 days & 11 & $(8,9)$ \\
\hline$<5$ & 67 & $(54,0)$ \\
\hline$\geq 5$ & 46 & $(37,1)$ \\
\hline Do not remember & & \\
\hline Number of clients in the last day & 47 & $(37,9)$ \\
\hline$<3$ & 69 & $(55,6)$ \\
\hline$\geq 3$ & 8 & $(6,5)$ \\
\hline Do not know/remember & & \\
\hline Number of clients in the past 7 days & 27 & $(21,8)$ \\
\hline$<10$ & 42 & $(33,9)$ \\
\hline$\geq 10$ & 55 & $(44,3)$ \\
\hline Do not know/remember & &
\end{tabular}


ISSN 1681-116X. Український соціум. 2016. № 1(56)

Table 3 continuation

\begin{tabular}{|c|c|c|}
\hline Number of occasional clients of the last 10 clients $^{\mathrm{a}}$ & & \\
\hline$<5$ & 14 & $(11,4)$ \\
\hline$\geq 5$ & 109 & $(88,6)$ \\
\hline Ever had anal sex with a man & 93 & $(75,0)$ \\
\hline Condom use & & \\
\hline Currently carrying condoms & 93 & $(75,0)$ \\
\hline Location last obtained a condom & & \\
\hline Apothecary & 68 & $(54,8)$ \\
\hline Peer/outreach staff & 26 & $(21,0)$ \\
\hline Other & 27 & $(21,8)$ \\
\hline Don't remember & 3 & $(2,4)$ \\
\hline
\end{tabular}

${ }^{\mathrm{a}}$ Valid $n=123$.

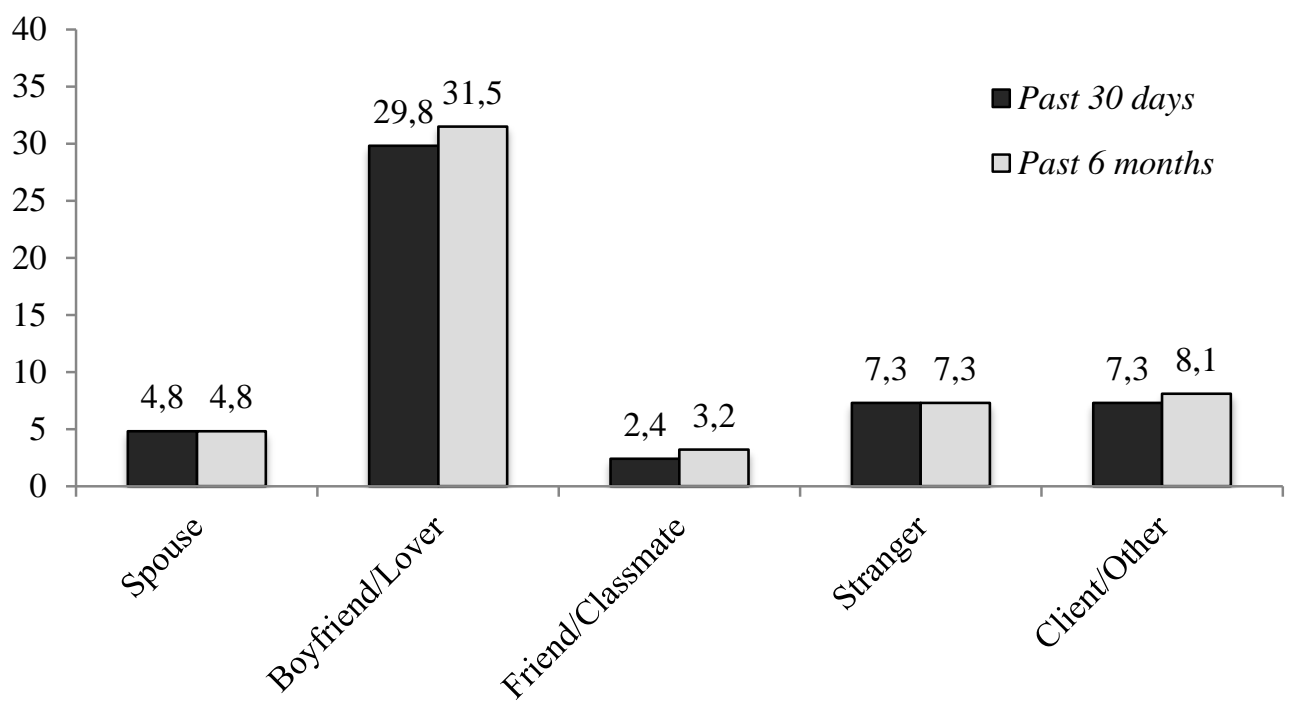

Figure 2. Types of sexual partners in the past one-month and past six months among female sex workers in Zaporizhzhya $(N=124), \%$

Condom use. Overall, the vast majority of CSW reported using a condom at their last sexual act, but fewer reported consistent condom use, both with regular and occasional clients (Figure 3). Consistent condom use was reported more frequently with occasional clients than with regular clients (76,8\% vs $64,5 \%)$. Three-quarters of CSW reported carrying condoms on them at the time of the interview, and over half $(54,8 \%)$ obtained condoms from apothecaries (Table 3$)$. 


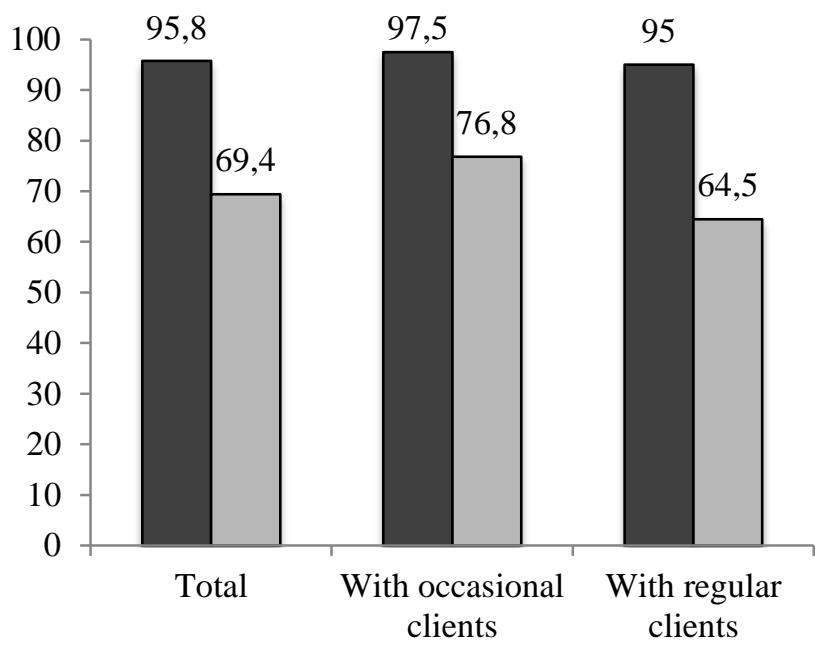

$\square$ Condom used at last $\operatorname{sex}(n=119)$

$\square$ Consistent condom use $(n=121)$

Figure 3. Condom use with regular clients and occasional clients among female sex workers in Zaporizhzhya, \%

Alcohol use. Alcohol use was commonly reported by CSW, as presented in Table 4. Nearly all participants indicated that they had consumed alcohol in the past one-month and $61,7 \%$ reported drinking excessively several times per week during that time. A large proportion of respondents disclosed that either they (41\%) or their clients $(35 \%)$ had been under the influence of alcohol most of the times they had sex in the past 30 days (Figure 4 ).

Table 4

Alcohol use, drug use, and injection behaviours among female sex workers in Zaporizhzhya $(N=124)$

\begin{tabular}{|c|c|c|}
\hline Alcohol use & $n$ & $\%$ \\
\hline \multicolumn{3}{|l|}{ Frequency of alcohol consumption in past 30 days $^{\mathrm{a}}$} \\
\hline Daily & 34 & $(28,6)$ \\
\hline Several times a week & 70 & $(58,8)$ \\
\hline Once per week/Several times per month & 14 & $(11,8)$ \\
\hline Not in past month & 1 & $(0,8)$ \\
\hline \multicolumn{3}{|l|}{ Frequency of excessive drinking in past 30 days $^{b}$} \\
\hline Daily & 8 & $(9,9)$ \\
\hline Several times a week & 50 & $(61,7)$ \\
\hline Once per week/Several times per month & 23 & $(28,4)$ \\
\hline \multicolumn{3}{|l|}{ Drug use } \\
\hline Ever used drugs & 63 & $(50,8)$ \\
\hline \multicolumn{3}{|l|}{ Age at start of drug use (years) ${ }^{\mathrm{c}}$} \\
\hline$<15$ & 26 & $(41,3)$ \\
\hline$\geq 15$ & 30 & $(47,6)$ \\
\hline Don't know/Don't remember & 7 & $(11,1)$ \\
\hline Mean age & \multicolumn{2}{|c|}{15,0} \\
\hline Ever injected $^{\mathrm{d}}$ & 26 & $(46,4)$ \\
\hline
\end{tabular}


ISSN 1681-116X. Український соціум. 2016. № 1(56)

Table 4 continuation

\begin{tabular}{|l|c|c|}
\hline \multicolumn{1}{|c|}{ Injection behaviours $^{e}$} & & \\
\hline Injected with first drug use $^{|c|}$ & 8 & $(31,1)$ \\
\hline Number of injections per day & & \\
\hline$\geq 2$ & 17 & $(65,4)$ \\
\hline$\leq 1$ & 9 & $(34,6)$ \\
\hline Use clean needle at each injection & 23 & $(88,5)$ \\
\hline Share needles/syringes & 3 & $(11,5)$ \\
\hline
\end{tabular}

${ }^{\mathrm{a}}$ Valid $n=119 ;{ }^{\mathrm{b}}$ Valid $n=81 ;{ }^{\mathrm{c}}$ Valid $n=63 ;{ }^{\mathrm{d}}$ Valid $n=56 ;{ }^{\mathrm{e}}$ Valid $n=26$.

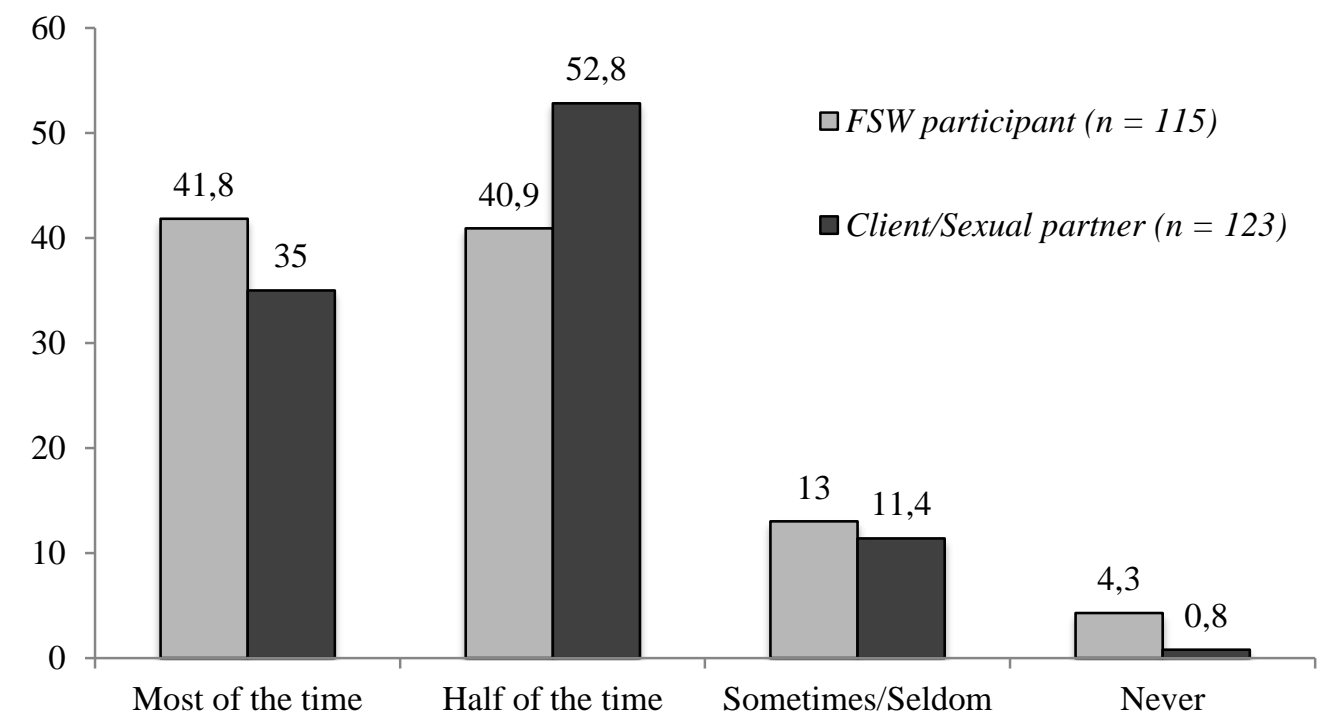

Figure 4. Alcohol consumption among female sex workers and their sexual partners (including clients) during sex acts in the past thirty days, \%

Drug use and injecting behaviours. As presented in Table 4, approximately half of CSW participants $(n=63)$ reported ever-using drugs, and the mean age of first drug use was 15 years. A further $46,4 \%(n=26)$ of those participants reported that they had ever injected, and $31,1 \%(n=8)$ indicated that their first time using drugs was by injection. Nearly two-thirds of the CSW who reported injecting drugs indicated that they injected more than twice in a day, but only $11,5 \%(n=3)$ reported needle/syringe sharing.

Among CSW reporting any drug use, marijuana and opium extracts were most commonly reported to be the first drugs ever used, while opium extracts and methamphetamines were most frequently used at first injection (Figure 5). 


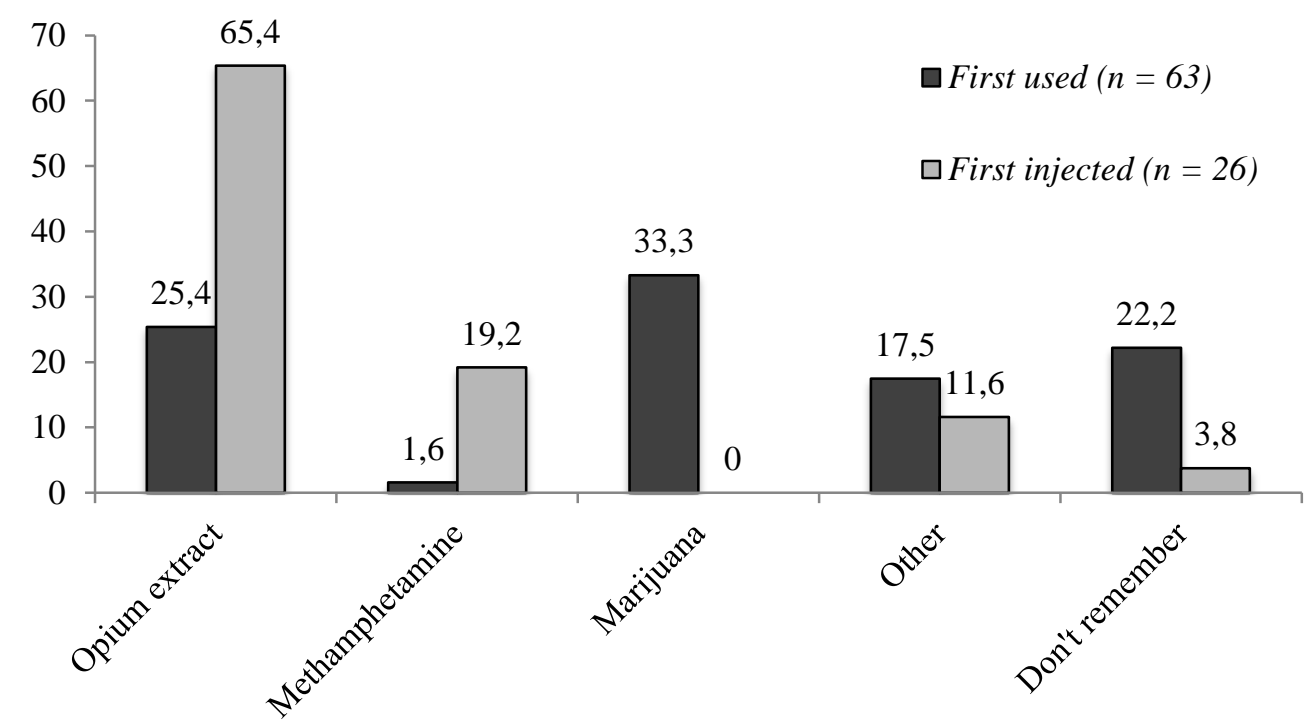

Figure 5. Drugs first used and first injected by female sex workers in Zaporizhzhya, \%

Experiences of sexual violence. In total, 49,2\% $(n=61)$ of CSW participants had ever been physically forced to have sex. Figure 6 illustrates that clients were the most common perpetrators of this violence, but members of the militsiya were also implicated.

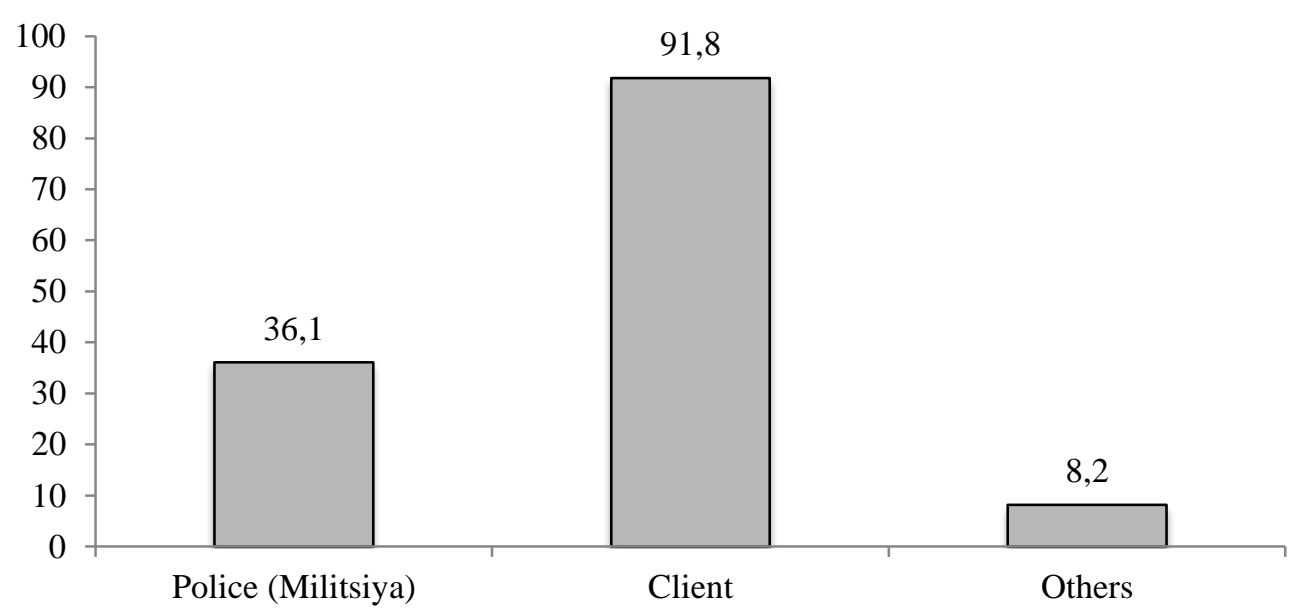

Figure 6. Perpetrators of sexual violence against female sex workers in Zaporizhzhya

$$
(n=61), \%
$$

Discussion. This study highlights numerous risk factors and vulnerabilities for HIV faced by CSW in Zaporizhzhya. Importantly, the young reported average age at entry into sex work poses some concern. A substantial body of literature indicates that young women involved in sex work are at 
increased risk of acquiring HIV and other sexually transmitted infections [23-26], and are less likely to access to HIV prevention services, when compared to older CSW [11; 12]. Indeed, national HIV reports indicate that young CSW ( $<25$ years) in Zaporizhzhya, when compared to older CSW $(\geq 25$ years), are disproportionately burdened by HIV infection [27], and are less likely to have been tested for HIV in the past twelve months or reached by existing programmes offering HIV prevention services [28]. Additionally, CSW in Zaporizhzhya report several sexual behaviours that may increase the likelihood of future HIV infection. In particular, relatively high average per-day and per-week client volumes which have been associated with increased HIV prevalence $[29 ; 30]$ and the commonness of engaging in anal sex pose notable risk to CSW in Zaporizhzhya. This risk is further compounded in the context of exceptionally low rates of HIV testing and inconsistent condom use, as reported by CSW participants. With this in mind, HIV prevention programmes in Zaporizhzhya must ensure that condom promotion and distribution efforts are reaching young CSW and women who are new to sex work.

Previous research has highlighted the key roles that injection drug use and sex work play in Ukraine's HIV epidemic [28;31;32]. In Zaporizhzhya, over one half of CSW that participated in this rapid epidemic appraisal endorsed injection drug use, the majority of whom reported injecting at least twice per day. Excessive alcohol use ‘several times per week' was also reported by participants, which is reflective of previous findings at the national level [28]. Given that vulnerability to HIV infection is significantly increased for CSW who inject drugs [33], access to HIV-related services is known to be limited for PWID in Ukraine [34], and excessive alcohol consumption has been associated with increases in risky sexual behaviours among young people in Ukraine [35], it is critical that HIV prevention programmes in Zaporizhzhya simultaneously promote and support conventional safe sexual practices, routine HIV testing, and harm reduction strategies including needle exchange and methadone programmes.

CSW in Zaporizhzhya commonly reported experiences of sexual violence at the hands of clients and police, echoing findings from other studies conducted in Eastern Europe [30;36] and globally [37; 38]. Structural interventions that include police sensitization programmes, policy level advocacy, and CSW community mobilization strategies are feasible and effective at reducing physical and sexual violence toward CSW [37; 39], and have been shown to significantly reduce rates of HIV infection among CSW [38]. As such, targeted HIV prevention programmes in Zaporizhzhya could greatly benefit from referring to existing models of structural interventions to reduce and prevent CSWtargeted violence to inform the development of similar programmes to suit the local context.

Based on findings from this rapid HIV epidemic appraisal in Zaporizhzhya, it is clear that while personal factors, such as engaging in risky sexual behaviours, injecting drugs, and consuming alcohol to excess, contribute to individual-level HIV risk, broader social and structural factors, including prevalent violence directed at CSW and limited access to condoms, HIV testing services, and drug and alcohol treatment programmes, are equally important in shaping the HIV risk environments. The uptake of a combination prevention approach that mixes behavioural, biomedical, and structural interventions, is specifically tailored to suit the local needs and contexts in which they are implemented, and is predicated on the principles of social justice and human rights, [9; 40] could enhance and expand upon local HIV prevention efforts, and contribute to the development of a rightsbased framework for stemming the HIV epidemic in Zaporizhzhya and Ukraine, generally.

Acknowledgements. First and foremost, the authors gratefully acknowledge the time and effort of all study participants and the hard work and dedication of field team members in Zaporizhzhya. We are also thankful for the input and support of partnering organisations and key stakeholders including Spodivannya, the Zaporizhzhya oblast chapter of the All Ukrainian Network of People Living with HIV, City Without Drugs, the Youth Friendly Clinic, and the Department of Health of Zaporizhzhya 
Oblast Administration. Finally, the authors thank the UISR research team for their support throughout the project, and UNICEF Ukraine, UNICEF Canada, and the ICID for funding the epidemic appraisal.

\section{References}

1. Zaller N., et al. Geographic Variability in HIV and Injection Drug Use in Ukraine: Implications for Integration and Expansion of Drug Treatment and HIV Care. Int J Drug Policy, 2015, No. 26.1, pp. 37-42.

2. World Health Organization. Surveillance Report: HIV/AIDS Surveillance in Europe: WHO Regional Office for Europe, 2012.

3. Bozicevic I., et al. The Emerging and Re-Emerging Human Immunodeficiency Virus Epidemics in Europe. Clin Microbiol Infect, 2013, No. 19.10, pp. 917-929.

4. Nizova N.M., et al. Vil-infektsiya v Ukraini: inform. byul., No. 44 [HIV Infections in Ukraine: Newsletter No. 44]. Kyiv, Institute of Epidemiology and Infectious Diseases after L. Gromashevskyi National Academy of Medical Sciences of Ukraine, 2015.

5. Kruglov Y.V., et al. The Most Severe HIV Epidemic in Europe: Ukraine's National HIV Prevalence Estimates for 2007. Sex Transm Infect, 2008, No. 84, Suppl 1, pp. i37-i41.

6. Jolley E., et al. HIV among People Who Inject Drugs in Central and Eastern Europe and Central Asia: A Systematic Review with Implications for Policy. BMJ Open, 2012, No. 2 (5).

7. Baral S., et al. Burden of HIV among Female Sex Workers in Low-Income and Middle-Income Countries: A Systematic Review and Meta-Analysis. Lancet Infect Dis, 2012, No. 12.7, pp. 538-549.

8. Busza J.R., et al. Street-Based Adolescents at High Risk of HIV in Ukraine. J Epidemiol Community Health, 2011, No. 65 (12), pp. 1166-1170.

9. UNAIDS. Combination HIV Prevention: Tailoring and Coordinating Biological, Behavioural and Structural Strategies to Reduce New HIV Infections. Geneva, Joint United Nations Programme on HIV/AIDS, 2010; Ukraine Harmonized AIDS Response Progress Report. Kyiv: UNAIDS, 2014.

10. Mishra S., et al. Characterizing Sexual Histories of Women before Formal Sex-Work in South India from a Cross-Sectional Survey: Implications for HIV/STI Prevention. BMC Public Health, 2012, No. 12, 829 p.

11. Ramakrishnan L., et al. Programme Coverage, Condom Use and STI Treatment among FSWs in a Large-Scale HIV Prevention Programme: Results from Cross-Sectional Surveys in 22 Districts in Southern India. Sex Transm Infect 86, 2010, Suppl 1, pp. i62-i68.

12. Zhang X.D., et al. Vulnerabilities, Health Needs and Predictors of High-Risk Sexual Behaviour among Female Adolescent Sex Workers in Kunming, China. Sex Transm Infect, 2013, No. 89 (3), pp. 237-244.

13. Goldenberg S.M., et al. Structural Barriers to Antiretroviral Therapy among Sex Workers Living with HIV: Findings of a Longitudinal Study in Vancouver, Canada. AIDS Behav, 2015.

14. Lyalina N., Nordenmark A. Analysis of the Progress, Remaining Challenges and Trends in Child Care System Reform: Armenia, Belarus, Georgia, Moldova and Ukraine. Chisinau, Moldova, UNICEF, 2009.

15. Hayward P. First Reduce Harm: Tackling HIV in Ukraine. Lancet, 2010, No. 376 (9749), 1287 p.

16. Vitek C.R., et al. Slowing of the HIV Epidemic in Ukraine: Evidence from Case Reporting and Key Population Surveys, 2005-2012. PLoS One, 2014, No. 9 (9), e103657 p.

17. Berleva G., et al. Analytical Report: Estimation of the Size of Populations Most-at-Risk for HIV Infection in Ukraine. Kyiv, International HIV/AIDS Alliance in Ukraine, 2012.

18. International HIV/AIDS Alliance in Ukraine. Annual Report 2014. Kyiv: International HIV/AIDS Alliance in Ukraine, 2014. 


\section{ISSN 1681-116X. Український соціум. 2016. № 1(56)}

19. Lavrakas P.J. Probability Proportional to Size (PPS) Sampling. Encyclopedia of Survey Research Methods. Ed. Lavrakas, P.J., SAGE Publications, Ltd., 2008, pp. 620-622.

20. Becker M., et al. Mapping of Key Populations, Services and an HIV Epidemic Appraisal in Zaporizhzhya, Ukraine: UNICEF Ukraine; Ukrainian Institute for Social Research after Olexandr Yaremenko; International Center for Infectious Diseases, Canada; The Centre for Global Public Health, Canada, 2014.

21. Bhattacharjee P., et al. Monitoring HIV Prevention Programme Outcomes among Key Populations in Kenya: Findings from a National Survey. PLoS One, 2015, No. 10 (8), e0137007.

22. «Сподівання» - Запорожский Благотворительньій Фонд [Spodivannya - Zaporizhia Chartiable Foundation]. Spodivannya 26 Oct 2015. Web. 18 Nov 2015.

23. Ramesh B.M., et al. Determinants of HIV Prevalence among Female Sex Workers in Four South Indian States: Analysis of Cross-Sectional Surveys in Twenty-Three Districts. AIDS 22, 2008, Suppl 5, pp. 35-44.

24. Sarkar K., et al. Young Age Is a Risk Factor for HIV among Female Sex Workers - an Experience from India. $J$ Infect, 2006, No. 53.4, pp. 255-259.

25. Silverman J.G. Adolescent Female Sex Workers: Invisibility, Violence and HIV. Archives of Disease in Childhood, 2011, No. 96 (5), pp. 478-481.

26. McClarty L.M., et al. Circumstances, Experiences and Processes Surrounding Women's Entry into Sex Work in India. Cult Health Sex, 2014, No. 16 (2), pp. 149-163.

27. Grushetsky A. Analytical Report: Behaviour Monitoring and HIV-Prevalence among Commercial Sex Workers as a Component of Second Generation Surveillance. Kiyv, International HIV/AIDS Alliance in Ukraine, 2012.

28. Balakireva O., et al. Summary of the Analytical Report: Monitoring the Behaviour and HIV-Infection Prevalence among Female Sex Workers as a Component of HIV Second Generation Surveillance. Kyiv, International HIV/AIDS Alliance in Ukraine, 2014.

29. Buzdugan R., et al. Devising a Female Sex Work Typology Using Data from Karnataka, India. International Journal of Epidemiology, 2010, No. 39.2, pp. 439-448.

30. Decker M.R., et al. Injection Drug Use, Sexual Risk, Violence and STI/HIV among Moscow Female Sex Workers. Sex Transm Infect, 2012, No. 88 (4), pp. 278-283.

31. Kyrychenko P., Polonets V. High HIV Risk Profile among Female Commercial Sex Workers in Vinnitsa, Ukraine. Sex Transm Infect, 2005, No. 81 (2), pp. 187-188.

32. Lowndes C.M., Alary M., Platt L. Injection Drug Use, Commercial Sex Work, and the HIV/STI Epidemic in the Russian Federation. Sex Transm Dis, 2003, No. 30 (1), pp. 46-48.

33. Wirtz A.L., et al. Current and Recent Drug Use Intensifies Sexual and Structural HIV Risk Outcomes among Female Sex Workers in the Russian Federation. Int J Drug Policy, 2015, No. 26 (8), pp. 755-763.

34. Spicer N., et al. It's Risky to Walk in the City with Syringes': Understanding Access to HIV/AIDS Services for Injecting Drug Users in the Former Soviet Union Countries of Ukraine and Kyrgyzstan. Global Health, 2011, No. 7, p. 22.

35. Pylypchuk R., Marston C. Factors Associated with Sexual Risk Behaviour among Young People in Ukraine. Cent Eur J Public Health, 2008, No. 16 (4), pp. 165-174.

36. Decker M.R., et al. Estimating the Impact of Reducing Violence against Female Sex Workers on Hiv Epidemics in Kenya and Ukraine: A Policy Modeling Exercise. Am J Reprod Immunol 69, 2013, No. Suppl 1, pp. 122-132.

37. Beattie T.S., et al. Violence against Female Sex Workers in Karnataka State, South India: Impact on Health, and Reductions in Violence Following an Intervention Program. BMC Public Health, 2010, No. 10, 476 p. 
38. Kerrigan D., et al. The Global HIV Epidemics among Sex Workers. Washington, D.C., The World Bank, 2013.

39. Gurnani V., et al. An Integrated Structural Intervention to Reduce Vulnerability to HIV and Sexually Transmitted Infections among Female Sex Workers in Karnataka State, South India. BMC Public Health, 2011, No. 11, 755 p.

40. Bekker L.G., et al. Combination HIV Prevention for Female Sex Workers: What Is the Evidence? Lancet, 2015, No. 385 (9962), pp. 72-87.

Отримано 22.12.15

Лі МакЛарті, Департамент громадського здоров’я, Центр глобального суспільного здоров'я (Манітоба, Канада),

Mapicса Беккер, Департамент громадського здоров'я, Центр глобального суспільного здоров'я (Манітоба, Канада),

Дарина Павлова, канд. соціол. наук, доцент, завсектором моніторингу та оцінки соціальних проектів ГО «Український інститут соціальних досліджень імені Олександра Яременка», Шаджі Ісак, Карнатакський траст з формування здорового способу життя (Бангалор, Індія), Фаран Еммануель, Департамент громадського здоров'я, Центр глобального суспільного здоров'я (Манітоба, Канада),

Ольга Балакірєва, канд. соціол. наук, заввіділом моніторингових досліджень соціальноекономічних трансформацій ДУ «Інститут економіки та прогнозування НАН України», голова правління ГО «Український інститут соціальних досліджень імені Олександра Яременка»,

Тетяна Бондар, канд. соціол. наук, директор ГО «Український інститут соціальних досліджень імені Олександра Яременка»,

Яна Сазонова, МБФ «Альянс громадського здоров'я»,

Олена Сакович, керівник проектів 3 питань здоров'я та розвитку молоді, Дитячий фонд ООН (ЮНІСЕФ),

Джеймс Бланшар, Департамент громадського здоров'я, Центр глобального суспільного здоров’я (Манітоба, Канада)

АНАЛІЗ УРАЗЛИВОСТІ ТА РИЗИКУ ІНФІКУВАННЯ ВІЛ СЕРЕД ОСБ У М. ЗАПОРІЖЖЯ

Запропоновано аналіз індивідуальних факторів ризику, а також соџіальної та структурної уразливості до інфікування ВІЛ, з якими стикаються ОСБ у м. Запоріжжя. Програми профілактики ВІЛ, які об'єднують поведінкові, медичні та структурні втручання, рекомендовано розширити, використовуючи існуючі місцеві напрацювання з профілактики як у м. Запоріжжя, так $і в$ Україні у иілому.

Ключові слова: ВІЛ, особи, залучені до секс-бізнесу, групи ризику, уразливі групи населення, програми профілактики ВІЛ. 
ISSN 1681-116X. Український соціум. 2016. № 1(56)

Ли МакЛарти, Департамент общественного здоровья, Центр глобального общественного здоровья (Манитоба, Канада),

Марисса Беккер, Департамент общественного здоровья, Центр глобального общественного здоровья (Манитоба, Канада),

Дарья Павлова, канд. социол. наук, доцент, завсектором мониторинга и оценки социальных проектов ОО «Украинский институт социальных исследований имени Александра Яременко», Шаджи Исак, Карнатакський траст по формированию здорового образа жизни (Бангалор, Индия),

Фаран Эммануэль, Департамент общественного здоровья, Центр глобального общественного здоровья (Манитоба, Канада),

Ольга Балакирева, канд. социол. наук, завотделом мониторинговых исследований социальноэкономических трансформаций ГУ «Институт экономики и прогнозирования НАН Украины», председатель правления ОО «Украинский институт социальных исследований имени Александра Яременко»,

Татьяна Бондарь, канд. социол. наук, директор ОО «Украинский институт социальных исследований имени Александра Яременко»,

Яна Сазонова, МБФ «Альянс общественного здоровья»,

Елена Сакович, руководитель проектов по вопросам здоровья и развития молодежи, Детский фонд ООН (ЮНИСЕФ),

Джеймс Бланшар, Департамент общественного здоровья, Центр глобального общественного здоровья (Манитоба, Канада)

\section{АНАЛИЗ УЯЗВИМОСТИ И РИСКА ИНФИЦИРОВАНИЯ ВИЧ СРЕДИ РКС В Г. ЗАПОРОЖЬЕ}

Предложен анализ индивидуальных факторов риска, а также сощиальной и структурной уязвимости к инфицированию ВИЧ, с которыми сталкиваются РКС в г. Запорожье. Программы профилактики ВИЧ, которые объединяют поведенческие, медицинские и структурные интервенции, рекомендуется расширить, используя существующце местные наработки по профилактике как в г. Запорожье, так и в Украине в целом.

Ключевые слова: ВИЧ, работники коммерческого секса, группы риска, уязвимые группы населения, программы профилактики ВИЧ. 